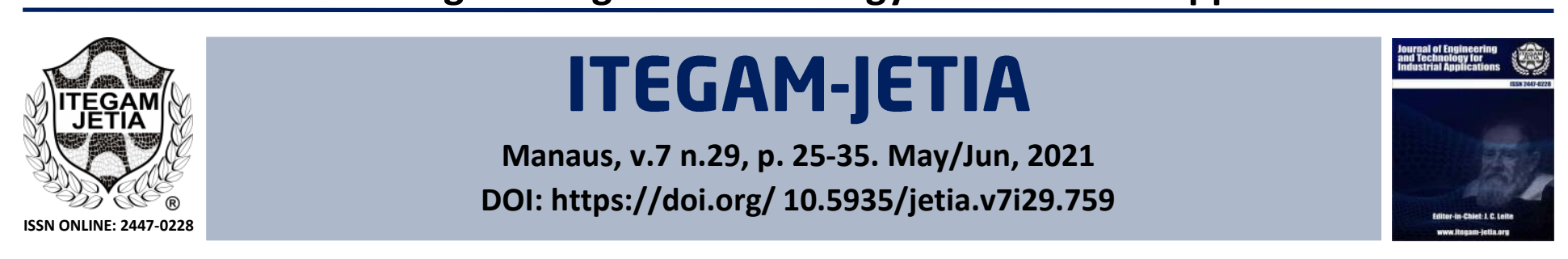

\title{
APPLICATION OF STATISTICAL PROCESS CONTROL (SPC) IN THE VOLUME VARIATION OF A VOLATILE LIQUID FUEL
}

\section{Everaldo de Queiroz Lima*1, Cecília Lenzi², Maurício Moyses Machado³ and Fátima Geisa Mendes Teixeira $^{4}$}

1, 2, ${ }^{4}$ Chemical Engineering, Lutheran University Center of Manaus - CEULM/ULBRA, Manaus, Amazonas, Brazil.

${ }^{3}$ University of Uberaba - UNIUBE. Uberaba, Minas Gerais, Brazil.

${ }^{1} \underline{\text { http://orcid.org/0000-0002-6887-4594 }}$ (i), ${ }^{2} \underline{\text { http://orcid.org/0000-0003-3123-0610 (i) }{ }^{3} \text { http://orcid.org/0000-0002-1106-980X }}$ (i)

Email: *everaldolima.am@gmail.com, cecilia.lenzi@yahoo.com.br, mauricioepga@gmail.com, fatimageisa2015@gmail.com

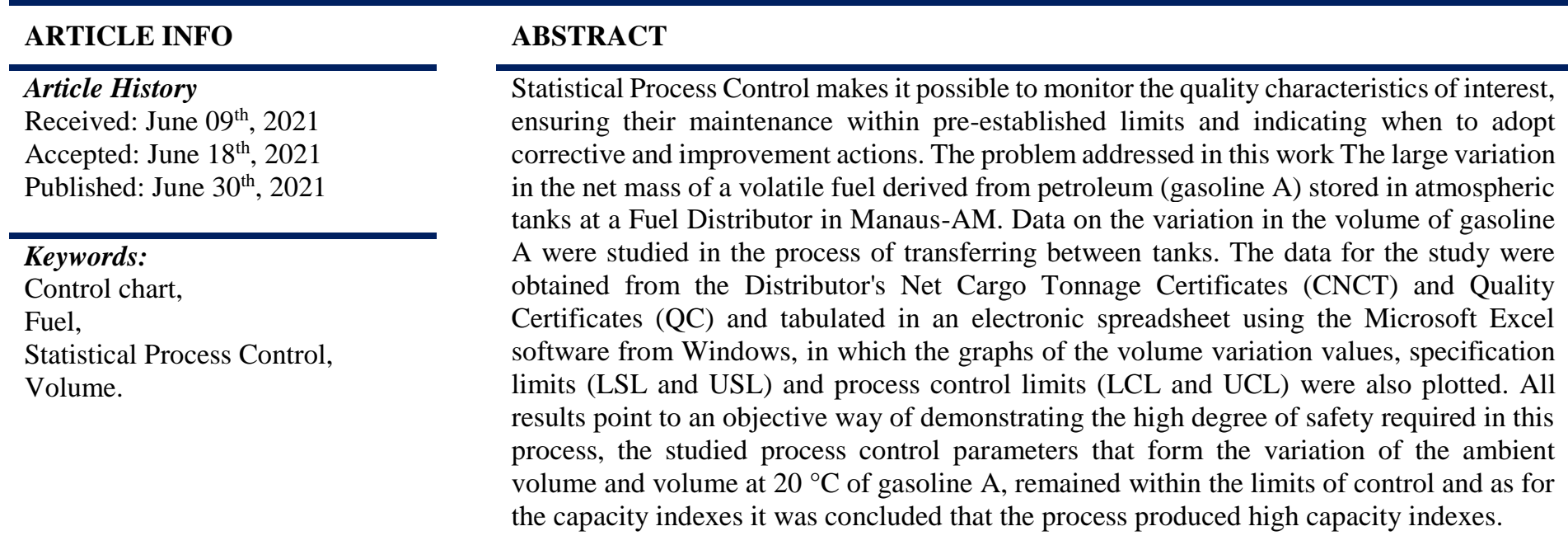

Copyright (C2016 by authors and Galileo Institute of Technology and Education of the Amazon (ITEGAM). This work is licensed under the Creative Commons Attribution International License (CC BY 4.0).

\section{INTRODUCTION}

Statistical Process Control (SPC) is a statistical technique applied to production that allows the systematic reduction of the variability in the characteristics of the quality of interest, contributing to the improvement of the intrinsic quality, productivity, reliability and cost of what is being produced [1]. The production, storage and transport of fuels in terms of volumetric quantity is a growing concern, the volume of fuels can be compromised from production at an oil refinery or biofuel plant to the final consumer tank. [2,3]. The amount of fuel in storage and distribution tanks can undergo several changes, causing the volume to differ from the amount of fuel that initially leaves what was produced $[2,4]$. The regulatory body for the activities that integrate the oil, natural gas and biofuels industries in Brazil, linked to the Ministry of Mines and Energy (MME), is the National Agency of Petroleum, Natural Gas and Biofuels (ANP), the federal agency that executes the national policy for the sector with a focus on ensuring fuel supply, product quality and protecting consumer interests [5].

\section{THEORETICAL REFERENCE}

\section{II.1 STATISTICAL PROCESS CONTROL}

The SPC is an inspection system by sampling, operating throughout the process, with the objective of verifying the presence of special causes, that is, causes that are not natural to the process and that can harm the quality of the manufactured product. Once the special causes are identified, we can act on them, continuously improving the production processes and, therefore, the quality of the final product. [6, 7]. The SPC makes it possible to monitor the quality characteristics of interest, ensuring their maintenance within pre-established limits and indicating when to adopt 
corrective and improvement actions. It allows the systematic reduction of variability in quality characteristics, in an effort to improve the intrinsic quality, productivity and reliability of what is being produced or supplied. Shewhart control charts stand out among the SPC tools for operational simplicity and effectiveness in detecting problems [8]. The SPC provides an x-ray of the process, identifying its variability and enabling the control of this variability over time through continuous data collection, analysis and blocking of possible special causes that are making the system unstable [7,9]. The main objective of the SPC is to enable an effective quality control, carried out by the operator himself in real time. This increases the operator's commitment to the quality of what is being produced and frees management for improvement tasks [9]. The SPC makes it possible to monitor the characteristics of interest, ensuring that they will remain within pre-established limits and indicating when corrective and improvement actions should be taken. It is important to emphasize the importance of detecting defects as early as possible, to avoid adding raw material and labor to a defective product [7].

\section{II.2 CONTROL GRAPHICS}

The SPC is operationalized through control charts, which are used to monitor the performance of a process from the definition of an acceptable control range. The control chart is used to analyze trends and patterns that happen over time. Its main purpose is to monitor a process, checking if it is under statistical control indicating its range of variation [6]. There are two types of control charts: for variables and for attributes. The control graphs for attributes refer to the quality characteristics that classify items in conforming and non-conforming, while the control graphs for variables are based on the measurement of quality characteristics on a continuous scale, as shown in Figure $1[6,7,9]$.

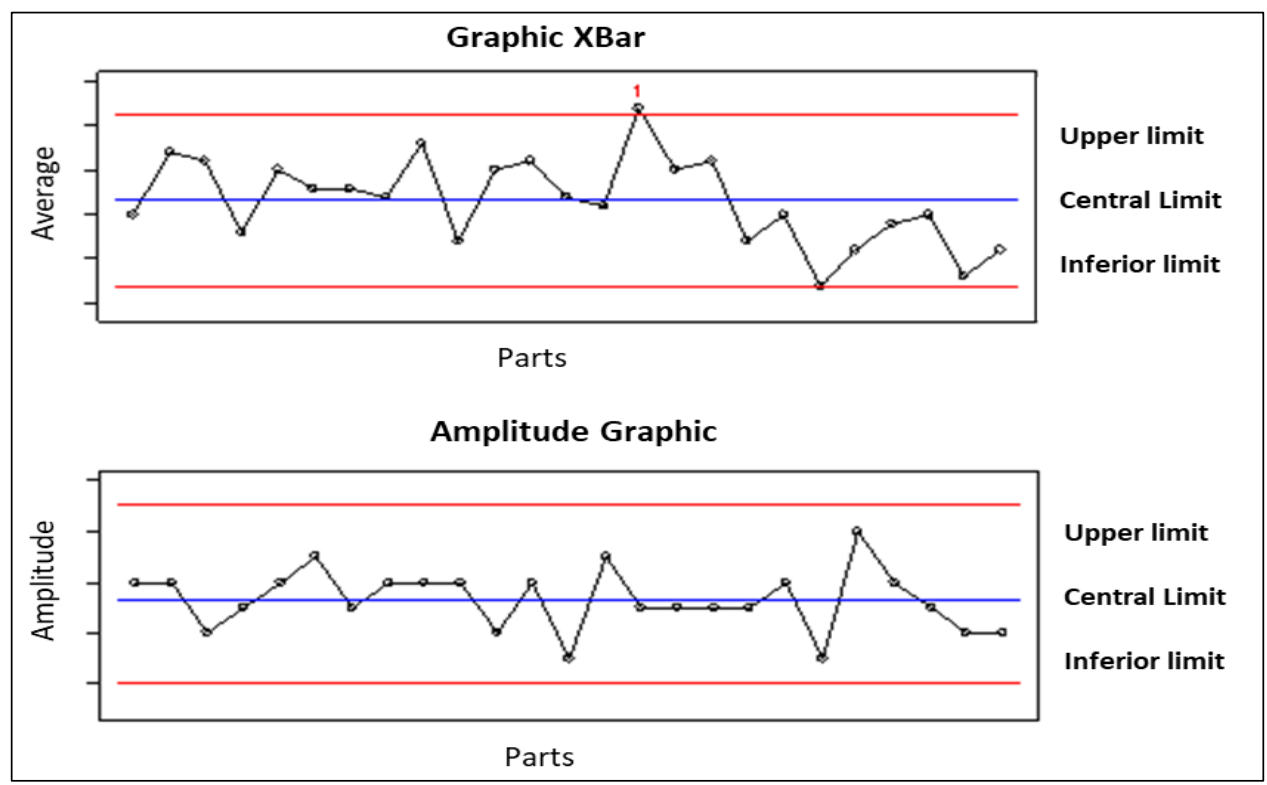

Figure 1: Control Chart Template.

Source: [17].

Figure 1 shows a control chart that is composed of a Central Line (CL) that represents the average value or central limit of the quality characteristic corresponding to the situation of the process under control and a pair of control limits: one of them located below the central line called Lower Control Limit (LCL) and another located above the central line, called Upper Control Limit (UCL) $[10,11]$.

\section{II.3 CONTROL LIMITS}

The control of the process is usually done through the control graph for individual values or gráfico graph. The variability of the process can be monitored either through the standard deviation control graph, called the $\mathrm{S}$ graph, or by the graph for the moving amplitude, called the $\mathrm{R}$ graph. To better exemplify the function of each graph, the $x$ graph monitors the variability between samples and the $\mathrm{S}$ or $\mathrm{R}$ graph monitors the variability within the sample. The points plotted on the control graphs are joined by straight lines sequentially and are interpreted according to horizontal lines, called UCL, ML and LCL given by Equations 1, 2 and 3 for the mean graph and 5, 6, and 7 for the graph of the moving range $[7,12]$.

Control limits for the graph of individual measures.

$$
\begin{gathered}
U C L_{x}=\bar{x}+E_{2} \cdot R m \\
L M_{x}=\bar{x} \\
L C L_{x}=\bar{x}-E_{2} \cdot R m
\end{gathered}
$$

Where:

$$
E_{2}=\frac{3}{d_{2}}
$$

Where $\bar{x}$ is the average of the graph points for each variable, $R m=\left|x_{i}-x_{i-1}\right|$, that is, the difference between two subsequent values for each variable, and the parameters $E_{2}$ and $d_{2}$ are tabulated $[7,12]$.

\section{II.4 VOLATILITY}

Volatility is a quantity that is related to the easiness of the substance to pass from the liquid to the vapor or gaseous state. This facility depends on the referential; therefore, volatility is always relative: it takes into account two substances, one of which is the reference substance $[10,13]$.

The relative volatility between a substance $\mathrm{A}$ and a substance B is defined as follows: 


$$
\alpha_{A B}=\frac{y_{A e} / x_{A e}}{y_{B e} / x_{B e}}
$$

Where: $\alpha_{A B}$ is the relative volatility between A and B. $y_{A e}$ and $y_{B e}$ are molar fractions of $\mathrm{A}$ and $\mathrm{B}$, respectively, in the vapor phase in equilibrium with the liquid phase. $x_{A e}$ and $x_{B e}$ they are molar fractions of $\mathrm{A}$ and $\mathrm{B}$, respectively, in the vapor phase in equilibrium with the liquid phase.

Relative volatility below one $\left(\alpha_{\mathrm{AB}}<1\right)$ indicates that $\mathrm{B}$ is more volatile than $\mathrm{A}$; otherwise, if the relative volatility is greater than one $\left(\alpha_{A B}>1\right), A$ is more volatile than $B$. If the liquid phase is an ideal mixture, Raoult's law can be accepted as valid:

$$
\begin{aligned}
& p_{A}=P_{A}^{s a t} \cdot x_{A} \\
& p_{B}=P_{B}^{s a t} \cdot x_{B}
\end{aligned}
$$

Where: $p_{A}$ and $p_{B}$, are partial pressures of $\mathrm{A}$ and $\mathrm{B}$, respectively. $P_{A}^{\text {sat }}$ and $P_{B}^{\text {sat }}$ are vapor pressures of $\mathrm{A}$ and $\mathrm{B}$, respectively. $x_{A}$ and $x_{B}$ are molar fractions of $\mathrm{A}$ and $\mathrm{B}$, respectively, in the liquid phase.

If the vapor phase is an ideal gas, Dalton's Law applies:

$$
\begin{aligned}
& y_{A}=\frac{p_{A}}{P} \\
& y_{B}=\frac{p_{B}}{P}
\end{aligned}
$$

Where: $y_{A}$ and $y_{B}$ are the molar fractions of $\mathrm{A}$ and $\mathrm{B}$, respectively, in the vapor phase. $\mathrm{P}$ the total system pressure.

Replacing the eq. (6) in eq. (8) and eq. (7) in eq. (9), we will have:

$$
\begin{aligned}
& y_{A}=\frac{P_{A}^{s a t} \cdot x_{A}}{P} \\
& y_{B}=\frac{P_{B}^{s a t} \cdot x_{B}}{P}
\end{aligned}
$$

Replacing the eq. (10) and eq. (11) in eq. (5), we will have:

$$
\alpha_{A B}=\frac{P_{A}^{s a t}}{P_{B}^{s a t}}
$$

That is, in cases of totally ideal liquid-vapor equilibrium, the relative volatility between two substances in a mixture is a simple relation of their vapor pressures $[10,13]$.

\section{MATERIALS AND METHODS}

\section{III.1 COMPANY DESCRIPTION - PLACE OF STUDY}

The work was carried out at a company in the oil sector in the city of Manaus, which has been operating since 2000 and has been consolidating its position as one of the largest distributors of petroleum fuels and biofuels in Brazil. As defined by the ANP, the company under study carries out the activity of distribution of liquid fuels that is of public utility and comprises the acquisition, storage, mixing, transportation, commercialization and quality control of fuels [14].

It recently underwent a process to expand its storage capacity, which went from $15.000 \mathrm{~m}^{3}$ to $75.000 \mathrm{~m}^{3}$, according to Regulatory Standard $n^{\circ} 20$ (NR-20) of the Ministry of Labor is classified as a class III hazardous facility and carries out storage, transfer, handling and handling of combustible and flammable liquids [15].

\section{III.2 STAGES OF WORK}

The work was carried out on the changes in the volume of gasoline A in the process of transfers between tanks, as described in Figure 2.

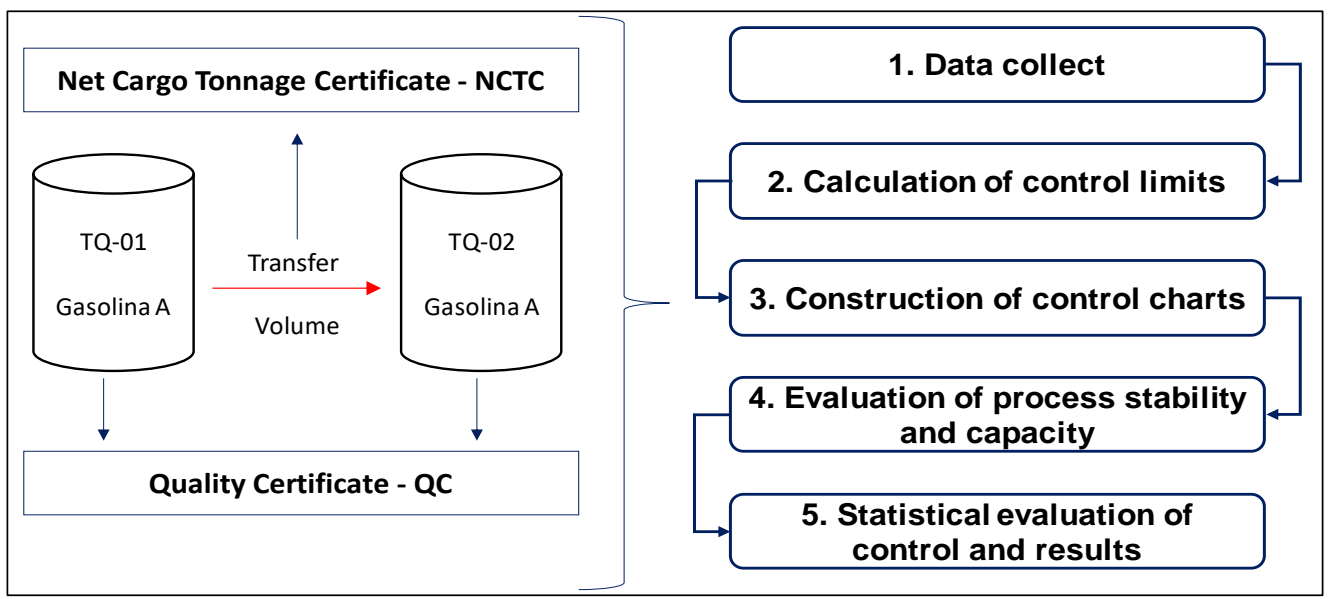

Figure 2: Fuel transfer flow and methodology flowchart. Source: [7] and [12].

\section{III.2.1 DATA COLLECT}

Gasoline A volume data were collected in the transfer between tanks (TQ) processes. As shown in figure 2, data on volume at room temperature and volume at $20{ }^{\circ} \mathrm{C}$ from TQ-01 (shipping tank) and TQ-02 (receiving tank) were collected over a period of two months. These data were obtained from Certificates of Net Cargo Tonnage (CNCT), which is the official document for certification and quantification of the volume of fuel handled in oil terminals. The data of temperature, density and specific gravity at $20{ }^{\circ} \mathrm{C}$ were obtained from the Gasoline A Quality Certificate (QC), referring to the batch of work in the sending tank and in the receiving tank.

\section{III.2.2 CALCULATION OF CONTROL LIMITS}

The control of the process was carried out through the control chart of individual values and by control charts for mobile amplitudes. The points plotted on the control graphs were joined by straight lines sequentially that were interpreted in terms of horizontal lines, called UCL, ML and LCL that took place according to the methodology of [7] and [12]. 


\section{III.2.3 CONSTRUCTION OF CONTROL GRAPHICS}

The volume data at room temperature and the volume converted at $20^{\circ} \mathrm{C}$ of the transfers were organized in a spreadsheet and plotted the graphs using Microsoft Excel software from Windows. They checked how the process behaves and made an average $(\bar{x})$ and mobile range $(\mathrm{Rm})$ of the data obtained to determine the UCL and the LCL to verify the expected standards of the process and define the limits according to the methodology proposed by [7], that defines the SCP for continuous and batch processes.

\section{III.2.4 EVALUATION OF PROCESS STABILITY AND CAPACITY}

The relationship between the levels of variability or the stability of the process in relation to the specification requirements, were made through the analysis of the capacity of the process. The verification of the ability of the process to safely meet the specifications was demonstrated by calculating the parameter $C_{p k}$, defined by Equations 13, 14 and 15. This parameter represents the ratio between the specification tolerance and the total dispersion of the process, according to the methodology of [7] and [12].

$$
\begin{gathered}
C_{p k}=\min \left[C_{p i}, C_{p s}\right] \\
C_{p i}=\frac{\bar{x}-L I E}{3 . s} \\
C_{p s}=\frac{L S E-\bar{x}}{3 . s}
\end{gathered}
$$

Where LSL is the Lower Specification Limit and USL is the Upper Specification Limit, the $s$ Where LSL is the Lower Specification Limit and USL is the Upper Specification Limit, the $\square$ is the average of the samples.

The index $C_{p k}$ evaluates the distance from the process average to the specification limits, taking the one that is less, that is, it is defined as being the lowest value between $C_{p i}$ and $C_{p s}$, therefore, more critical in terms of the chances of producing outof-specification items. If $C_{p k} \leq 1$ (unable process), $1 \leq C_{p k} \leq$ 1,33 (acceptable process) e $C_{p k} \geq 1,33$ (capable process).

\section{III.2.5 STATISTICAL EVALUATION OF CONTROL AND RESULTS}

Data that exceeded the limit lines were verified and other Quality/Process engineering tools were used, such as Brainstorm and Ishikawa Diagram, which are discussions of ideas and a graphical form used as an analysis to represent influencing factors (causes) on a given problem. (effect) to find the root cause and define the process capacity indices [16].

\section{RESULTS AND DISCUSSIONS}

The data of 33 transfers (samples) of Gasoline A from tank 01 to tank 02 in the months of August and September 2020 were studied. Observations of process control related to the parameters of volume at room temperature and volume at $20{ }^{\circ} \mathrm{C}$ were used. The information collected from the NCTC and product QC are

\begin{tabular}{|c|c|c|c|c|c|c|c|c|c|c|c|c|}
\hline \multirow[b]{2}{*}{$\mathbf{N}^{\circ}$. } & \multicolumn{6}{|c|}{ Dispatcher Tank (TQ 01) } & \multicolumn{6}{|c|}{ Receiving Tank (TQ 02) } \\
\hline & $\begin{array}{c}\text { Tank } \\
\text { temp. } \\
\left({ }^{\circ} \mathrm{C}\right) \\
\end{array}$ & $\begin{array}{c}\text { Dens. } \\
\text { read } \\
\left(\mathrm{g} / \mathrm{cm}^{3}\right)\end{array}$ & $\begin{array}{c}\text { Sample } \\
\text { temp. } \\
\left({ }^{\circ} \mathrm{C}\right)\end{array}$ & $\begin{array}{c}\text { Esp. Mass } \\
\text { at } 20^{\circ} \mathrm{C} \\
\left(\mathrm{kg} / \mathrm{m}^{3}\right) \\
\end{array}$ & $\begin{array}{c}\text { Ambient } \\
\text { volume } \\
\text { (L) }\end{array}$ & $\begin{array}{l}\text { Volume at } \\
20^{\circ} \mathrm{C}(\mathrm{L})\end{array}$ & $\begin{array}{c}\text { Tank } \\
\text { temp. } \\
\left({ }^{\circ} \mathrm{C}\right) \\
\end{array}$ & $\begin{array}{c}\text { Dens. } \\
\text { read } \\
\left(\mathrm{g} / \mathrm{cm}^{3}\right)\end{array}$ & $\begin{array}{c}\text { Sample } \\
\text { temp. } \\
\left({ }^{\circ} \mathrm{C}\right)\end{array}$ & $\begin{array}{c}\text { Esp. Mass } \\
\text { at } 20^{\circ} \mathrm{C} \\
\left(\mathrm{kg} / \mathrm{m}^{3}\right) \\
\end{array}$ & $\begin{array}{c}\text { Ambient } \\
\text { volume (L) }\end{array}$ & $\begin{array}{l}\text { Volume at } \\
20^{\circ} \mathrm{C}(\mathrm{L})\end{array}$ \\
\hline 1 & 31,5 & 0,712 & 29,5 & 719,9 & 1.241 .029 & 1.224 .236 & 30,5 & 0,717 & 30,0 & 725,2 & $1.243 .243,0$ & 1.228 .130 \\
\hline 2 & 31,0 & 0,718 & 30,0 & 726,2 & 1.250 .090 & 1.234 .216 & 30,0 & 0,717 & 29,0 & 724,4 & $1.254 .595,0$ & 1.240 .037 \\
\hline 3 & 29,0 & 0,721 & 28,5 & 728,0 & 1.070 .774 & 1.059 .712 & 28,0 & 0,718 & 27,5 & 724,2 & $1.073 .099,0$ & 1.063 .134 \\
\hline 4 & 30,0 & 0,715 & 28,0 & 721,6 & 1.935 .762 & 1.013 .110 & 29,0 & 0,720 & 28,0 & 726,6 & 1.931 .089 & 1.911 .055 \\
\hline 5 & 30,0 & 0,710 & 28,5 & 717,1 & 997.157 & 985.329 & 29,0 & 0,708 & 27,5 & 714,3 & 995.546 & 984.831 \\
\hline 6 & 29,0 & 0,706 & 28,5 & 713,1 & 964.288 & 953.874 & 28,0 & 0,704 & 26,5 & 709,5 & 964.287 & 954.930 \\
\hline 7 & 29,5 & 0,707 & 28,0 & 713,7 & 1.026 .635 & 1.014 .950 & 28,5 & 0,712 & 28,0 & 718,7 & 1.028 .494 & 1.018 .176 \\
\hline 8 & 28,0 & 0,705 & 27,5 & 711,3 & 330.876 & 327.683 & 27,0 & 0,702 & 26,0 & 707,1 & 330.652 & 327.825 \\
\hline 9 & 28,0 & 0,714 & 26,0 & 719,0 & 912.786 & 904.177 & 27,0 & 0,710 & 26,5 & 715,4 & 914.522 & 906.896 \\
\hline 10 & 28,5 & 0,712 & 27,5 & 720,2 & 776.243 & 768.446 & 27,5 & 0,717 & 26,5 & 724,4 & 776.845 & 770.046 \\
\hline 11 & 29,0 & 0,717 & 28,5 & 724,0 & 1.406 .613 & 1.391 .908 & 28,0 & 0,720 & 26,5 & 725,3 & 1.409 .735 & 1.396 .690 \\
\hline 12 & 29,0 & 0,717 & 27,0 & 722,8 & 1.032 .362 & 1.021 .530 & 28,0 & 0,722 & 27,0 & 727,7 & 1.033 .674 & 1.024 .177 \\
\hline 13 & 28,0 & 0,716 & 26,5 & 721,4 & 219.162 & 217.110 & 27,0 & 0,715 & 26,5 & 720,4 & 218.192 & 216.399 \\
\hline 14 & 28,5 & 0,709 & 28,0 & 715,7 & 908.299 & 899.106 & 27,5 & 0,706 & 26,5 & 711,5 & 908.623 & 900.407 \\
\hline 15 & 27,5 & 0,711 & 26,0 & 716,0 & 832.622 & 825.195 & 26,5 & 0,716 & 25,0 & 720,1 & 833.066 & 826.706 \\
\hline 16 & 29,5 & 0,703 & 29,0 & 710,6 & 1.575 .481 & 1.557 .381 & 28,5 & 0,701 & 27,5 & 707,4 & 1.579 .472 & 1.563 .082 \\
\hline 17 & 31,5 & 0,705 & 29,5 & 713,0 & 512.228 & 505.152 & 30,5 & 0,703 & 29,5 & 711,0 & 513.398 & 506.886 \\
\hline 18 & 31,0 & 0,710 & 30,0 & 718,3 & 1.153 .299 & 1.138 .303 & 30,0 & 0,715 & 28,5 & 722,0 & 1.155 .210 & 1.141 .709 \\
\hline 19 & 29,0 & 0,713 & 28,5 & 720,0 & 1.200 .225 & 1.187 .528 & 28,0 & 0,710 & 27,0 & 715,8 & 1.203 .303 & 1.191 .847 \\
\hline 20 & 30,0 & 0,719 & 28,0 & 725,6 & 1.098 .599 & 1.085 .895 & 29,0 & 0,715 & 28,0 & 721,6 & 1.098 .678 & 1.087 .110 \\
\hline 21 & 30,0 & 0,720 & 28,5 & 727,0 & 414.281 & 409.510 & 29,0 & 0,725 & 27,5 & 731,1 & 412.711 & 408.487 \\
\hline 22 & 29,0 & 0,721 & 28,5 & 728,0 & 913.011 & 902.528 & 28,0 & 0,724 & 27,0 & 729,7 & 914.090 & 905.741 \\
\hline 23 & 29,5 & 0,720 & 28,0 & 726,6 & 1.218 .226 & 1.206 .291 & 28,5 & 0,725 & 27,5 & 731,1 & 1.220 .256 & 1.208 .463 \\
\hline 24 & 28,0 & 0,717 & 27,5 & 723,2 & 1.017 .680 & 1.008 .202 & 27,0 & 0,716 & 25,5 & 720,6 & 1.017 .412 & 1.009 .057 \\
\hline 25 & 28,0 & 0,710 & 26,0 & 715,0 & 1.059 .505 & 1.049 .393 & 27,0 & 0,707 & 28,5 & 714,1 & 1.062 .680 & 1.053 .784 \\
\hline 26 & 28,5 & 0,707 & 27,5 & 713,3 & 476.090 & 471.237 & 27,5 & 0,712 & 27,0 & 717,8 & 476.378 & 472.152 \\
\hline 27 & 29,0 & 0,706 & 28,5 & 713,1 & 454.002 & 449.099 & 28,0 & 0,704 & 27,0 & 709,9 & 455.905 & 451.487 \\
\hline 28 & 29,0 & 0,707 & 27,0 & 712,9 & 928.658 & 918.621 & 28,0 & 0,705 & 27,5 & 711,3 & 927.966 & 919.011 \\
\hline 29 & 28,0 & 0,705 & 26,5 & 710,5 & 561.877 & 556.441 & 27,0 & 0,710 & 26,0 & 715,0 & 562.394 & 557.698 \\
\hline 30 & 28,5 & 0,714 & 28,0 & 720,6 & 1.769 .183 & 1.751 .539 & 27,5 & 0,711 & 26,5 & 716,4 & 1.773 .054 & 1.757 .258 \\
\hline 31 & 27,5 & 0,712 & 26,0 & 717,0 & 1.112 .712 & 1.102 .816 & 26,5 & 0,708 & 25,5 & 712,6 & 1.112 .855 & 1.104 .166 \\
\hline 32 & 29,5 & 0,711 & 29,0 & 718,5 & 1.039 .391 & 1.027 .729 & 28,5 & 0,716 & 27,5 & 722,2 & 1.042 .358 & 1.032 .011 \\
\hline 33 & 28,0 & 0,717 & 26,0 & 722,0 & 1.028 .154 & 1.018 .543 & 27,0 & 0,720 & 26,0 & 724,9 & 1.026 .245 & 1.017 .927 \\
\hline
\end{tabular}
described in Table 1.

Table 1: Data collected from CACL and QC for transfers of Gasoline A (33 samples - August and September 2020). 


\section{IV.1 ASSESSMENT OF AMBIENT VOLUME VARIATION}

Figure 3 shows the graph of the values collected from the variation in the ambient volume of Gasoline A for 33 transfers, it is observed that the process remains within the specification limits, which are established NBR 13787 and ANP Resolution $N^{\circ}$ 23/2004 $[18,19]$, which are $-0,6$ and $+0,6 \%$ of volume variation for LSL and USL, respectively.
Figure 4 shows the control chart of the individual values for the Ambient Volume parameter for the 33 lots. It is observed that the process remains within the control limits, which were calculated for the process, which are $-0,34$ and $+0,52 \%$ for the LCL and UCL, respectively, with a mean (ML) around $+0,09 \%$ for the control chart of individual values $(x)$.

The values of specification limit and control limit for individual values, evaluating the parameter of ambient volume were organized in a spreadsheet and are shown in Table 2.

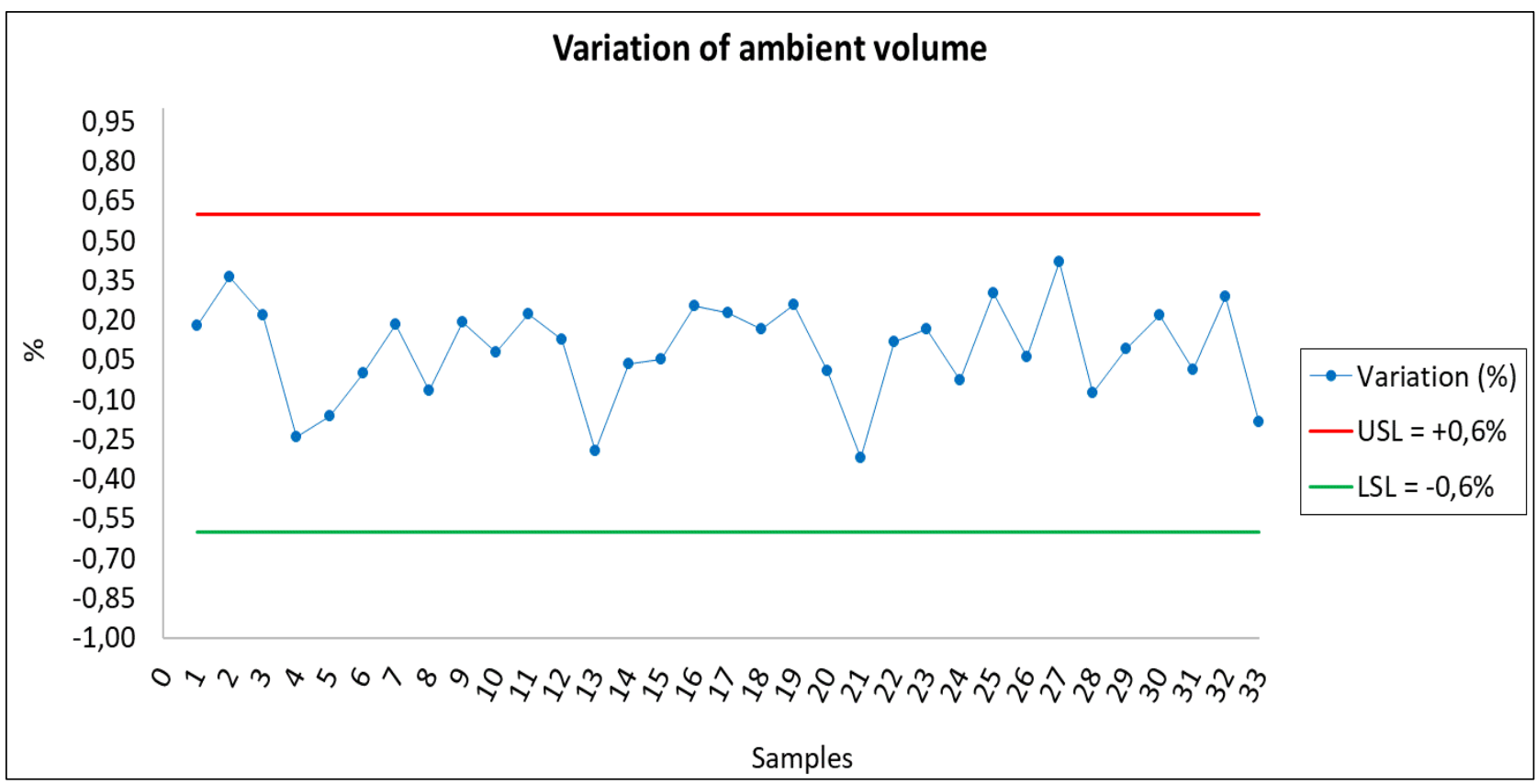

Figure 3: Graph of values and specification limits for Ambient Volume.

Source: Authors, (2020).

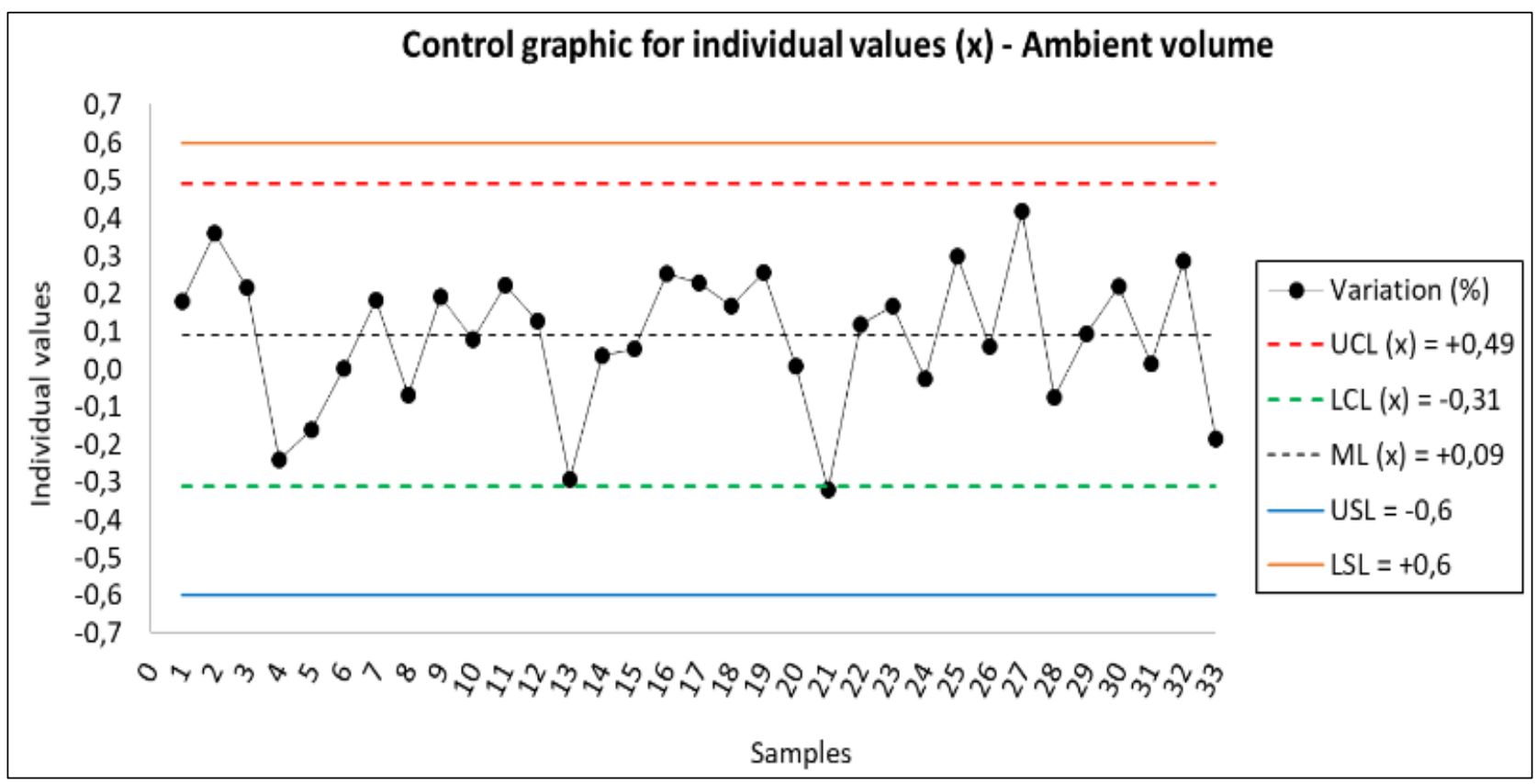

Figure 4: Control chart of individual values $(x)$ - Ambient volume.

Source: Authors, (2020). 
Lima et al., ITEGAM-JETIA, Manaus, v.7, n.29, p. 25-35, May/Jun, 2021.

Table 2: Volume variation (\%) in transfers between tanks (33 samples - August and September 2020).

\begin{tabular}{|c|c|c|c|c|c|c|c|c|}
\hline \multirow[b]{2}{*}{$\mathbf{N}^{0}$. } & \multicolumn{4}{|c|}{ Ambient Volume (L) } & \multicolumn{4}{|c|}{ Volume at $20^{\circ} \mathrm{C}(\mathrm{L})$} \\
\hline & $\begin{array}{c}\text { Dispatched } \\
\left(\mathrm{V}_{\mathrm{TQ1}}\right)\end{array}$ & $\begin{array}{c}\text { Received } \\
\left(\mathbf{V}_{\mathrm{TQ} 2}\right)\end{array}$ & $\begin{array}{c}\text { Difference } \\
\left(V_{\mathrm{TQ2}} \cdot \mathrm{V}_{\mathrm{TQ1}}\right)\end{array}$ & $\begin{array}{c}\text { Variation ambiente } \\
\text { volume }(\%)\end{array}$ & $\begin{array}{c}\text { Dispatched } \\
\left(\mathrm{V}_{\mathrm{TQ1}}\right)\end{array}$ & $\begin{array}{c}\text { Received } \\
\left(\mathbf{V}_{\mathrm{TQ} 2}\right)\end{array}$ & $\begin{array}{c}\text { Difference } \\
\left(V_{\mathrm{TQ2}}-V_{\mathrm{TQ1}}\right)\end{array}$ & $\begin{array}{c}\text { Variation volume at } \\
20^{\circ} \mathrm{C}(\%)\end{array}$ \\
\hline 1 & 1.241 .029 & 1.243 .243 & 2.214 & 0,18 & 1.224 .236 & 1.228 .130 & 3.894 & 0,32 \\
\hline 2 & 1.250 .090 & 1.254 .595 & 4.505 & 0,36 & 1.234 .216 & 1.240 .037 & 5.821 & 0,47 \\
\hline 3 & 1.070 .774 & 1.073 .099 & 2.325 & 0,22 & 1.059 .712 & 1.063 .134 & 3.422 & 0,32 \\
\hline 4 & 1.935 .762 & 1.931 .089 & -4.673 & $-0,24$ & 1.913 .110 & 1.911 .055 & -2.055 & $-0,11$ \\
\hline 5 & 997.157 & 995.546 & -1.611 & $-0,16$ & 985.329 & 984.831 & -498 & $-0,05$ \\
\hline 6 & 964.288 & 964.287 & -1 & 0,00 & 953.874 & 954.930 & 1.056 & 0,11 \\
\hline 7 & 1.026 .635 & 1.028 .494 & 1.859 & 0,18 & 1.014 .950 & 1.018 .176 & 3.226 & 0,32 \\
\hline 8 & 330.876 & 330.652 & -224 & $-0,07$ & 327.683 & 327.825 & 142 & 0,04 \\
\hline 9 & 912.786 & 914.522 & 1.736 & 0,19 & 904.177 & 906.896 & 2.719 & 0,30 \\
\hline 10 & 776.243 & 776.845 & 602 & 0,08 & 768.446 & 770.046 & 1.600 & 0,21 \\
\hline 11 & 1.406 .613 & 1.409 .735 & 3.122 & 0,22 & 1.391 .908 & 1.396 .690 & 4.782 & 0,34 \\
\hline 12 & 1.032 .362 & 1.033 .674 & 1.312 & 0,13 & 1.021 .530 & 1.024 .177 & 2.647 & 0,26 \\
\hline 13 & 219.162 & 218.192 & -970 & $-0,29$ & 217.110 & 216.399 & -711 & $-0,17$ \\
\hline 14 & 908.299 & 908.623 & 324 & 0,04 & 899.106 & 900.407 & 1.301 & 0,14 \\
\hline 15 & 832.622 & 833.066 & 444 & 0,05 & 825.195 & 826.706 & 1.511 & 0,18 \\
\hline 16 & 1.575 .481 & 1.579 .472 & 3.991 & 0,25 & 1.557 .381 & 1.563 .082 & 5.701 & 0,37 \\
\hline 17 & 512.228 & 513.398 & 1.170 & 0,23 & 505.152 & 506.886 & 1.734 & 0,34 \\
\hline 18 & 1.153 .299 & 1.155 .210 & 1.911 & 0,17 & 1.138 .303 & 1.141 .709 & 3.406 & 0,30 \\
\hline 19 & 1.200 .225 & 1.203 .303 & 3.078 & 0,26 & 1.187 .528 & 1.191 .847 & 4.319 & 0,36 \\
\hline 20 & 1.098 .599 & 1.098 .678 & 79 & 0,01 & 1.085 .895 & 1.087 .110 & 1.215 & 0,11 \\
\hline 21 & 414.281 & 412.711 & -1.570 & $-0,32$ & 409.510 & 408.487 & -1.023 & $-0,19$ \\
\hline 22 & 913.011 & 914.090 & 1.079 & 0,12 & 902.528 & 905.741 & 3.213 & 0,36 \\
\hline 23 & 1.218 .226 & 1.220 .256 & 2.030 & 0,17 & 1.206 .291 & 1.208 .463 & 2.172 & 0,18 \\
\hline 24 & 1.017 .680 & 1.017 .412 & -268 & $-0,03$ & 1.008 .202 & 1.009 .057 & 855 & 0,08 \\
\hline 25 & 1.059 .505 & 1.062 .680 & 3.175 & 0,30 & 1.049 .393 & 1.053 .784 & 4.391 & 0,42 \\
\hline 26 & 476.090 & 476.378 & 288 & 0,06 & 471.237 & 472.152 & 915 & 0,19 \\
\hline 27 & 454.002 & 455.905 & 1.903 & 0,42 & 449.099 & 451.487 & 2.388 & 0,53 \\
\hline 28 & 928.658 & 927.966 & -692 & $-0,07$ & 918.621 & 919.011 & 390 & 0,04 \\
\hline 29 & 561.877 & 562.394 & 517 & 0,09 & 556.441 & 557.698 & 1.257 & 0,23 \\
\hline 30 & 1.769 .183 & 1.773 .054 & 3.871 & 0,22 & 1.751 .539 & 1.757 .258 & 5.719 & 0,33 \\
\hline 31 & 1.112 .712 & 1.112 .855 & 143 & 0,01 & 1.102 .816 & 1.104 .166 & 1.350 & 0,12 \\
\hline 32 & 1.039 .391 & 1.042 .358 & 2.967 & 0,29 & 1.027 .729 & 1.032 .011 & 4.282 & 0,42 \\
\hline 33 & 1.028 .154 & 1.026 .245 & -1.909 & $-0,19$ & 1.018 .543 & 1.017 .927 & -616 & $-0,06$ \\
\hline
\end{tabular}

Source: Authors, (2020).

\section{IV.2 ASSESSMENT OF VOLUME VARIATION AT $20^{\circ} \mathrm{C}$}

Figure 5 shows the graph of the values collected from the volume variation at $20{ }^{\circ} \mathrm{C}$ of Gasoline A for 33 transfers, it is observed that the process remains within the specification limits, which are established by NBR 13787 and resolution ANP $n^{\circ}$ $23 / 2004[18,19]$, which are $-0,6$ and $+0,6 \%$ of volume variation for LSL and USL, respectively.

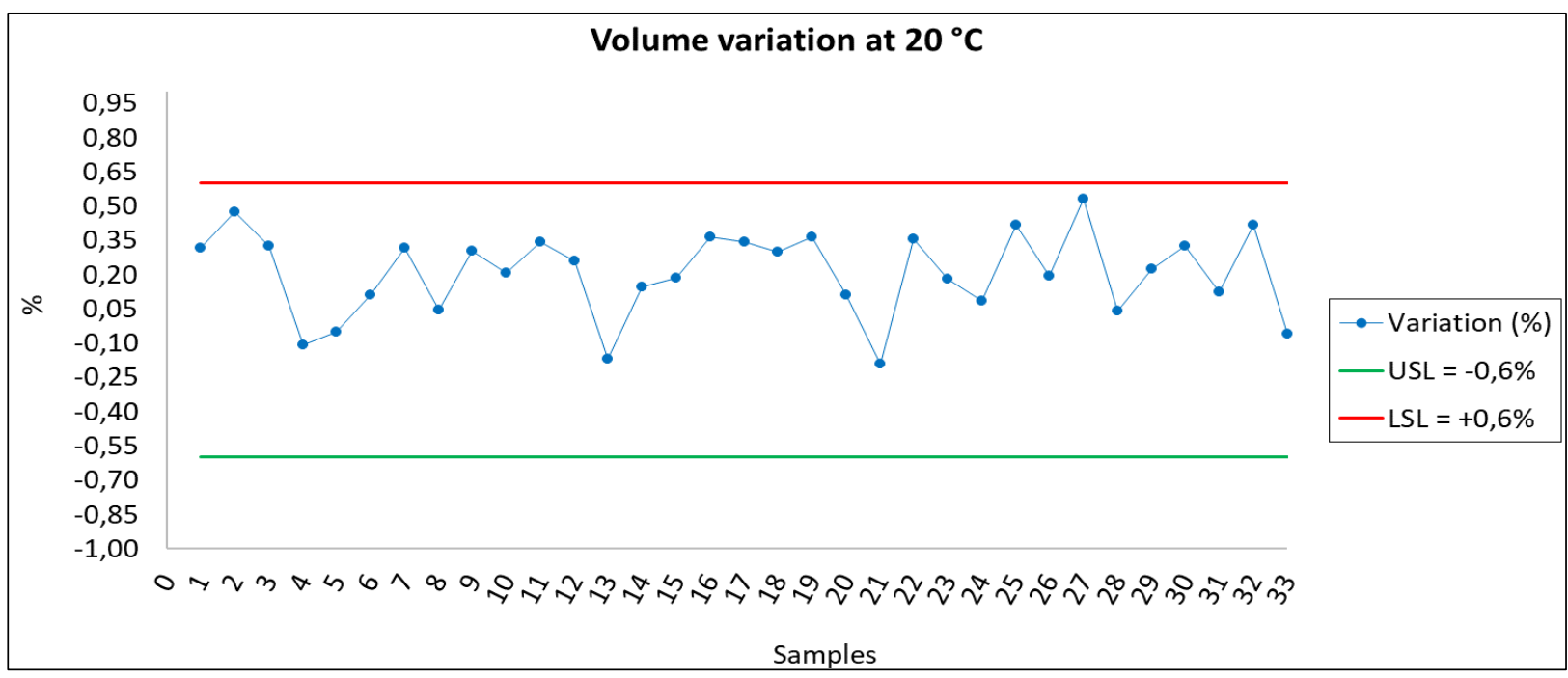

Figure 5: Graph of values and specification limits for Volume at $20{ }^{\circ} \mathrm{C}$.

Source: Author (2020).

Figure 6 shows the control chart of the individual values for the Volume parameter at $20{ }^{\circ} \mathrm{C}$ for the 33 lots. It is observed that the process remains within the control limits, which were calculated for the process, which are $-0,19$ and $+0,61 \%$ for LCL and UCL, respectively, with an average (LM) around $+0,21 \%$ for the control chart of individual values $(x)$. 


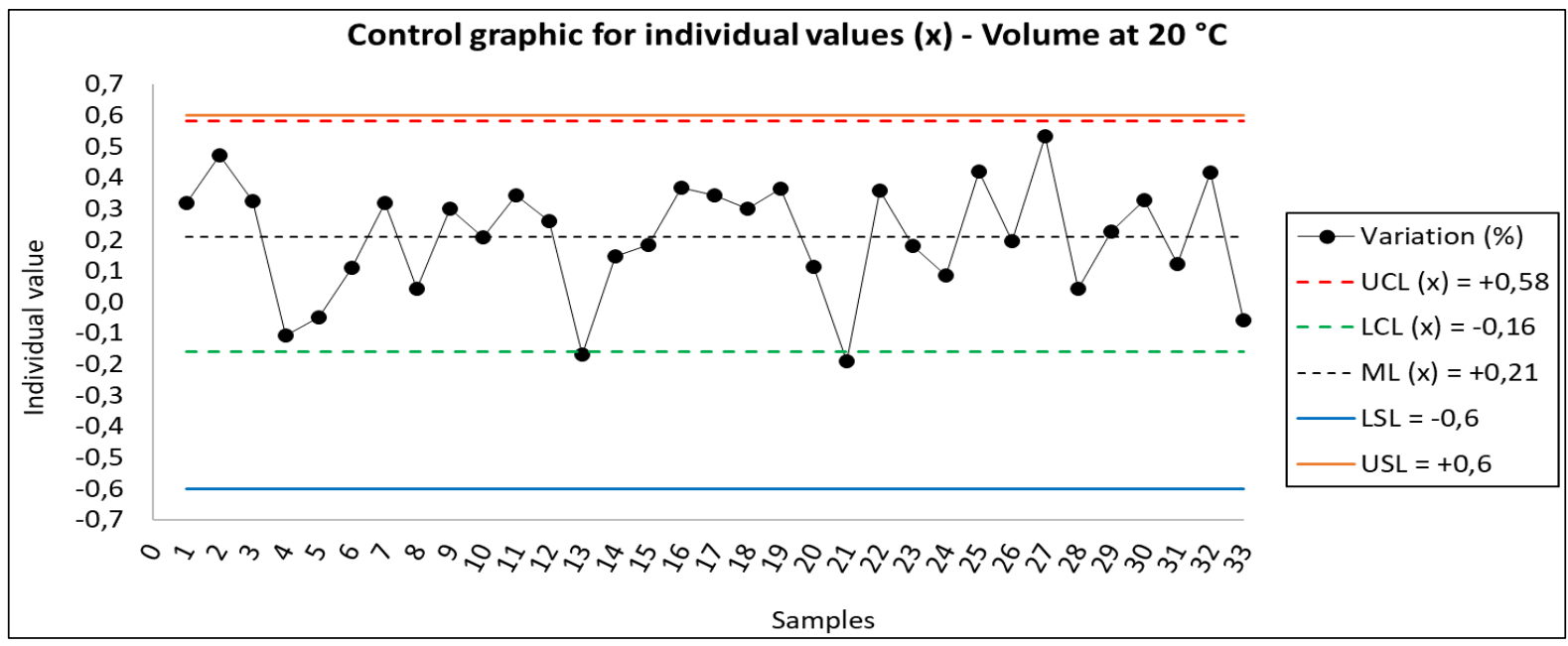

Figura 6: Control chart of individual values $(x)$-Volume at $20^{\circ} \mathrm{C}$.

Source: Authors, (2020).

The values of specification limit and control limit for individual values, evaluating the volume parameter at $20{ }^{\circ} \mathrm{C}$, were organized in a spreadsheet and are shown in Table 2.

\section{IV.3 PROCESS CAPABILITY ASSESSMENT}

After proving the stability of the process, the process capacity index was calculated as described in Table 3 .

Table 3: Control limits and capacity study.

\begin{tabular}{|c|c|c|}
\hline Parameter & Ambient volume & Volume at 20 ${ }^{\mathbf{C}}$ \\
\hline Especification limits & $-0,6 \mathrm{a}+0,6 \%$ & $-0,6 \mathrm{a}+0,6 \%$ \\
\hline Control limits (x) & $-0,31 \mathrm{a}+0,49 \%$ & $-0,16 \mathrm{a}+0,58 \%$ \\
\hline Standard deviation & 0,184 & 0,184 \\
\hline Cpi & 1,245 & 1,463 \\
\hline Cps & 0,931 & 0,712 \\
\hline Cpk = mín[Cpi,Cps] & $\mathbf{0 , 9 3 1}$ & $\mathbf{0 , 7 1 2}$ \\
\hline Conclusion & Inability process & Inability process \\
\hline
\end{tabular}

Source: Authors, (2020).
For the Ambient Volume variable, the value of $C_{p k}=0,931$, considering the standard deviation calculated for the 0,184 . Having resulted $C_{p k} \leq 1,33$ the process is qualified as Incapable.

For the variable Volume at $20^{\circ} \mathrm{C}$, the value of $C_{p k}=0,712$, considering the standard deviation calculated for the 0,184 . Having resulted $C_{p k} \leq 1,33$ the process is qualified as Incapable.

\section{IV.4 ACTION PLAN}

Since, according to the result of the Process Capacity Index $\left(C_{p k}\right)$, the process was considered Incapable, in this condition a brainstorm (sharing of ideas) was carried out in which everyone involved in the fuel transfer process (liquid bulk operator, operations supervisor and research student) exposed the ideas for surveying the causes that resulted in the undesired effect and from this survey, a Cause-Effect Diagram or Ishikawa Diagram was built, as shown in Figure 7.

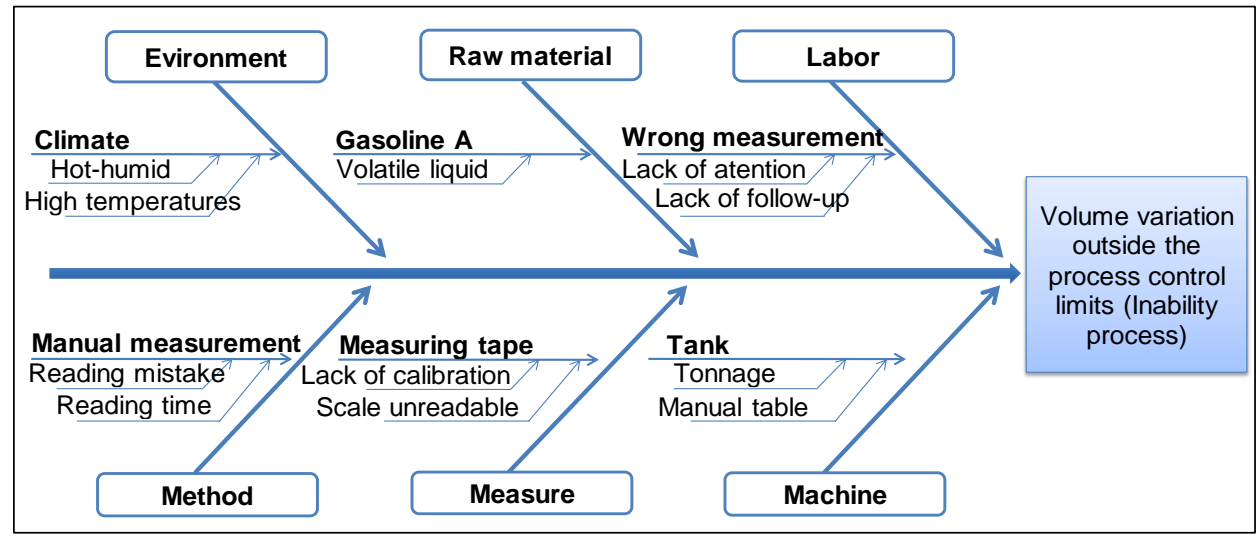

Figure 7: Ishikawa Diagram (cause-efectt) for volume variation.

Source: Authors, (2020).

From the Cause-Effect Diagram, a check-list was elaborated in which the variables and causes that led to the unwanted effect were listed. For each cause discussed for the process, it was verified whether or not the company met the requirement to inhibit the effect, and by elimination, work on the root cause.

As described in the check-list, the root cause of the unwanted effect for the process was the labor variable, which is caused by the wrong measurement that originated from the lack of attention during measurements and the lack of monitoring of a third party regarding the process carried out.
Once the root cause was verified, the data of 15 more transfers of Gasoline A from tank 01 to tank 02 were studied in October 2020 to review the fuel transfer process. The activity was monitored by an operations supervisor and the student researcher and carried out by the liquid bulk operator.

Observations of process control related to the parameters of volume at room temperature and volume at $20^{\circ} \mathrm{C}$ were used. The information collected from the product quality certificates received and ANP specifications are described in Table 4 and Table 5. 
Lima et al., ITEGAM-JETIA, Manaus, v.7, n.29, p. 25-35, May/Jun, 2021.

Table 4: Data collected from CACL and QC for transfers of Gasoline A (15 samples - October 2020 - process review).

\begin{tabular}{|c|c|c|c|c|c|c|c|c|c|c|c|c|}
\hline \multirow[b]{2}{*}{$\mathbf{N}^{\circ}$. } & \multicolumn{6}{|c|}{ Dispatcher Tank (TQ 01) } & \multicolumn{6}{|c|}{ Receiving Tank (TQ 02) } \\
\hline & $\begin{array}{l}\text { Tank } \\
\text { temp. } \\
\left({ }^{\circ} \mathrm{C}\right) \\
\end{array}$ & $\begin{array}{c}\text { Dens. } \\
\text { read } \\
\left(\mathrm{g} / \mathrm{cm}^{3}\right)\end{array}$ & $\begin{array}{c}\text { Sample } \\
\text { temp. } \\
\left({ }^{\circ} \mathrm{C}\right)\end{array}$ & $\begin{array}{c}\text { Esp. Mass } \\
\text { at } 20^{\circ} \mathrm{C} \\
\left(\mathrm{kg} / \mathrm{m}^{3}\right)\end{array}$ & $\begin{array}{c}\text { Ambient } \\
\text { volume (L) }\end{array}$ & $\begin{array}{c}\text { Volume } \\
\text { at } 20^{\circ} \mathrm{C} \\
(\mathrm{L})\end{array}$ & $\begin{array}{c}\text { Tank } \\
\text { temp. } \\
\left({ }^{\circ} \mathrm{C}\right) \\
\end{array}$ & $\begin{array}{c}\text { Dens. } \\
\text { read } \\
\left(\mathrm{g} / \mathrm{cm}^{3}\right)\end{array}$ & $\begin{array}{c}\text { Sample } \\
\text { temp. } \\
\left({ }^{\circ} \mathrm{C}\right) \\
\end{array}$ & $\begin{array}{c}\text { Esp. Mass } \\
\text { at } 20^{\circ} \mathrm{C} \\
\left(\mathrm{kg} / \mathrm{m}^{3}\right) \\
\end{array}$ & $\begin{array}{c}\text { Ambient } \\
\text { volume } \\
\text { (L) }\end{array}$ & $\begin{array}{c}\text { Volume } \\
\text { at } 20^{\circ} \mathrm{C} \\
(\mathrm{L})\end{array}$ \\
\hline $\mathbf{1}$ & 30,0 & 0,719 & 28,0 & 725,6 & 1.098 .599 & 1.085 .895 & 29,0 & 0,715 & 28,0 & 721,6 & 1.098 .678 & 1.087 .110 \\
\hline 2 & 30,0 & 0,710 & 28,5 & 717,1 & 997.157 & 985.329 & 29,0 & 0,708 & 27,5 & 714,3 & 995.546 & 984.831 \\
\hline $\mathbf{3}$ & 29,0 & 0,721 & 28,5 & 728,0 & 913.011 & 902.528 & 28,0 & 0,724 & 27,0 & 729,7 & 914.090 & 905.741 \\
\hline 4 & 27,5 & 0,711 & 26,0 & 716,0 & 832.622 & 825.195 & 26,5 & 0,716 & 25,0 & 720,1 & 833.066 & 826.706 \\
\hline 5 & 28,0 & 0,717 & 27,5 & 723,2 & 1.017 .680 & 1.008 .202 & 27,0 & 0,716 & 25,5 & 720,6 & 1.017 .412 & 1.009 .057 \\
\hline 6 & 28,0 & 0,705 & 26,5 & 710,5 & 561.877 & 556.441 & 27,0 & 0,710 & 26,0 & 715,0 & 562.394 & 557.698 \\
\hline 7 & 28,5 & 0,709 & 28,0 & 715,7 & 908.299 & 899.106 & 27,5 & 0,706 & 26,5 & 711,5 & 908.623 & 900.407 \\
\hline 8 & 28,5 & 0,707 & 27,5 & 713,3 & 476.090 & 471.237 & 27,5 & 0,712 & 27,0 & 717,8 & 476.378 & 472.152 \\
\hline 9 & 29,0 & 0,717 & 27,0 & 722,8 & 1.032 .362 & 1.021 .530 & 28,0 & 0,722 & 27,0 & 727,7 & 1.033 .674 & 1.024 .177 \\
\hline 10 & 29,0 & 0,707 & 27,0 & 712,9 & 928.658 & 918.621 & 28,0 & 0,705 & 27,5 & 711,3 & 927.966 & 919.011 \\
\hline 11 & 29,0 & 0,706 & 28,5 & 713,1 & 964.288 & 953.874 & 28,0 & 0,704 & 26,5 & 709,5 & 964.287 & 954.930 \\
\hline 12 & 28,0 & 0,705 & 27,5 & 711,3 & 330.876 & 327.683 & 27,0 & 0,702 & 26,0 & 707,1 & 330.652 & 327.825 \\
\hline 13 & 27,5 & 0,712 & 26,0 & 717,0 & 1.112 .712 & 1.102 .816 & 26,5 & 0,708 & 25,5 & 712,6 & 1.112 .855 & 1.104 .166 \\
\hline 14 & 28,5 & 0,712 & 27,5 & 720,2 & 776.243 & 768.446 & 27,5 & 0,717 & 26,5 & 724,4 & 776.845 & 770.046 \\
\hline 15 & 29,5 & 0,720 & 28,0 & 726,6 & 1.218 .226 & 1.206 .291 & 28,5 & 0,725 & 27,5 & 731,1 & 1.220 .256 & 1.208 .463 \\
\hline
\end{tabular}

Source: Authors, (2020).

Table 5: Volume variation (\%) in transfers between tanks (15 samples - October 2020 - process review).

\begin{tabular}{|c|c|c|c|c|c|c|c|c|}
\hline \multirow[b]{2}{*}{$\mathbf{N}^{\circ}$. } & \multicolumn{4}{|c|}{ Ambient Volume (L) } & \multicolumn{4}{|c|}{ Volume at $20^{\circ} \mathrm{C}(\mathrm{L})$} \\
\hline & $\begin{array}{c}\text { Dispatched } \\
\left(\mathbf{V}_{\mathrm{TQ1}}\right)\end{array}$ & $\begin{array}{c}\text { Received } \\
\left(\mathbf{V}_{\mathrm{TQ} 2}\right)\end{array}$ & $\begin{array}{c}\text { Difference } \\
\left(\mathbf{V}_{\mathrm{TQ2} 2} \cdot \mathbf{V}_{\mathrm{TQ1} 1}\right) \\
\end{array}$ & $\begin{array}{c}\text { Variation ambiente } \\
\text { volume }(\%)\end{array}$ & $\begin{array}{c}\text { Dispatched } \\
\left(\mathbf{V}_{\mathrm{TQ1}}\right)\end{array}$ & $\begin{array}{c}\text { Received } \\
\left(\mathbf{V}_{\mathrm{TQ} 2}\right)\end{array}$ & $\begin{array}{c}\text { Difference } \\
\left(\mathbf{V}_{\mathrm{TQ} 2}-\mathbf{V}_{\mathrm{TQ} 1}\right)\end{array}$ & $\begin{array}{c}\text { Variation volume at } \\
20^{\circ} \mathrm{C}(\%) \\
\end{array}$ \\
\hline 1 & 1.098 .599 & 1.098 .678 & 79 & 0,01 & 1.085 .895 & 1.087 .110 & 1.215 & 0,11 \\
\hline 2 & 997.157 & 995.546 & -1.611 & $-0,16$ & 985.329 & 984.831 & -498 & $-0,05$ \\
\hline 3 & 913.011 & 914.090 & 1.079 & 0,12 , & 902.528 & 905.741 & 3.213 & 0,36 \\
\hline 4 & 832.622 & 833.066 & 444 & 0,05 & 825.195 & 826.706 & 1.511 & 0,18 \\
\hline 5 & 1.017 .680 & 1.017 .412 & -268 & $-0,03$ & 1.008 .202 & 1.009 .057 & 855 & 0,08 \\
\hline 6 & 561.877 & 562.394 & 517 & 0,09 & 556.441 & 557.698 & 1.257 & 0,23 \\
\hline 7 & 908.299 & 908.623 & 324 & 0,04 & 899.106 & 900.407 & 1.301 & 0,14 \\
\hline 8 & 476.090 & 476.378 & 288 & 0,06 & 471.237 & 472.152 & 915 & 0,19 \\
\hline 9 & 1.032 .362 & 1.033 .974 & 1.312 & 0,13 & 1.021 .530 & 1.024 .177 & 2.647 & 0,26 \\
\hline 10 & 928.658 & 927.966 & -692 & $-0,07$ & 918.621 & 919.011 & 390 & 0,04 \\
\hline 11 & 964.288 & 964.287 & -1 & 0,00 & 953.874 & 954.930 & 1.056 & 0,11 \\
\hline 12 & 330.876 & 330.652 & -224 & $-0,07$ & 327.683 & 327.825 & 142 & 0,04 \\
\hline 13 & 1.112 .712 & 1.112 .855 & 143 & 0,01 & 1.102 .816 & 1.104 .166 & 1.350 & 0,12 \\
\hline 14 & 776.243 & 776.845 & 602 & 0,08 & 768.446 & 770.046 & 1.600 & 0,21 \\
\hline 15 & 1.218 .226 & 1.220 .256 & 2.030 & 0,17 & 1.206 .291 & 1.208 .463 & 2.172 & 0,18 \\
\hline
\end{tabular}

Source: Authors, (2020).

IV.4.1 Assessment of Ambient Volume Variation - Process Review

Figure 8 shows the graph of the values collected from the variation in the ambient volume of Gasoline A for 15 transfers, it is observed that the process remains within the specification limits, which are established by NBR 13787 and ANP resolution $\mathrm{n}^{\circ}$ $23 / 2004[18,19]$, which are $-0,6$ and $+0,6 \%$ of the volume variation for the USL and LSL, respectively.

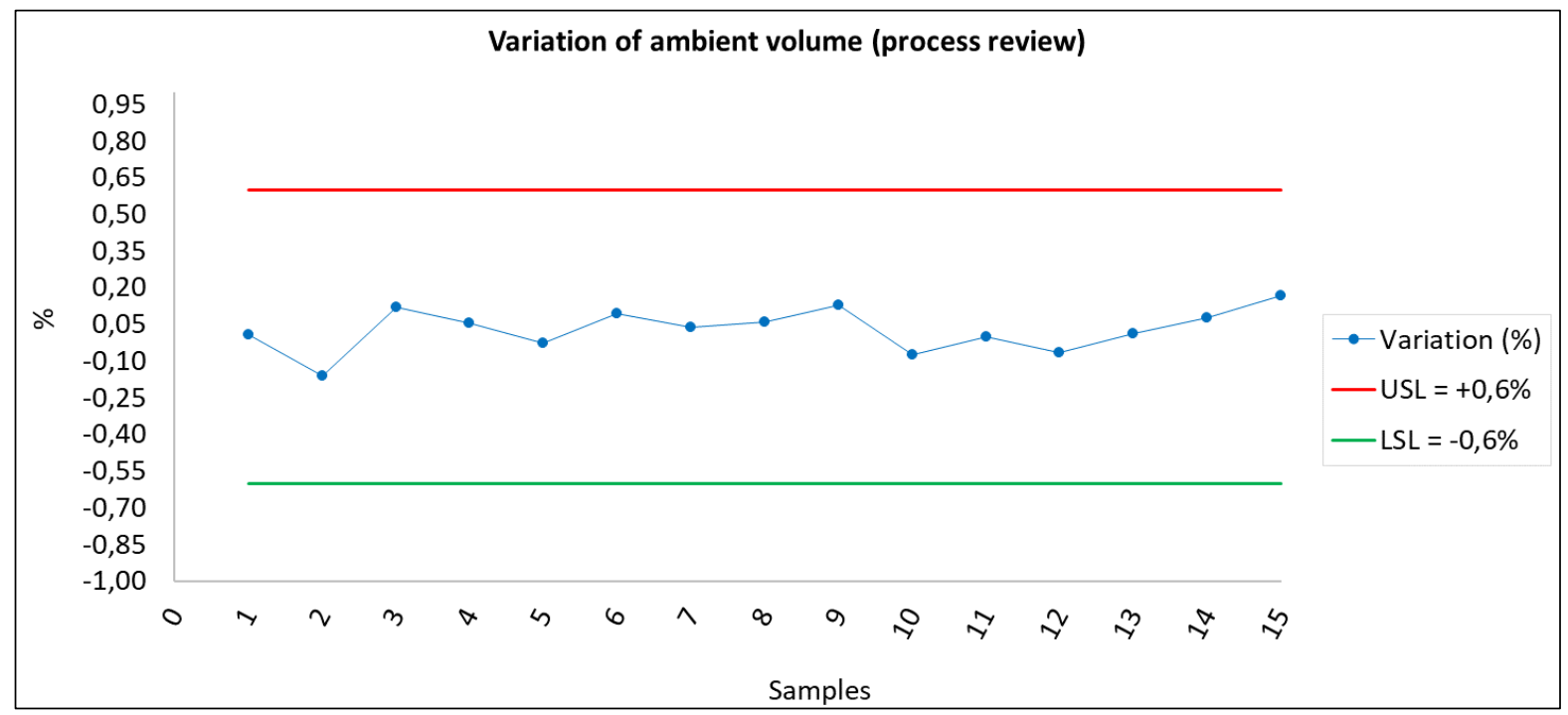

Figure 8: Graph of values and specification limits for Ambient Volume - process review.

Source: Author (2020). 
Figure 9 shows the control chart of the individual values for the parameter of the Ambient Volume for the 15 samples. It is observed that the process remains within the control limits, which were calculated for the process, which are $-0,26$ and $+0,32 \%$ for the LCL and UCL, respectively, with an average (ML) around $+0,03 \%$ for the control chart of individual values $(x)$.

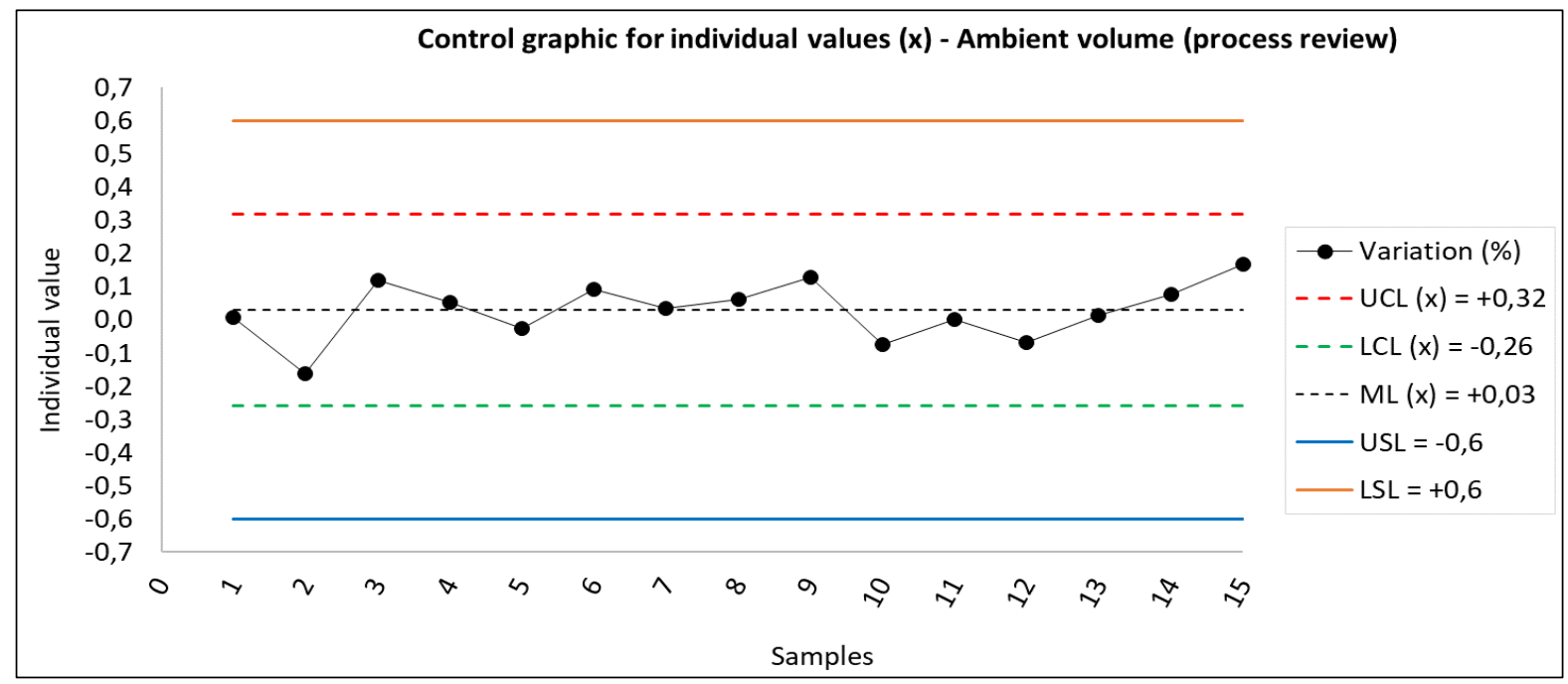

Figure 9: Control chart of individual values ( $x$ ) - Ambient volume (process review).

Source: Authors, (2020).

The values of specification limit and control limit for individual values, evaluating the parameter of ambient volume for review of the process were organized in a spreadsheet and are presented in Table 5.

IV.4.2 Assessment of Volume Variation at $20{ }^{\circ} \mathrm{C}-$ Process Review
Figure 10 shows the graph of the values collected from the volume variation at $20{ }^{\circ} \mathrm{C}$ of Gasoline A for 15 transfers, it is observed that the process remains within the specification limits, which are established by NBR 13787 and resolution ANP ${ }^{\circ}$ $23 / 2004[18,19]$, which are $-0,6$ and $+0,6 \%$ of volume variation for LSL and USL, respectively.

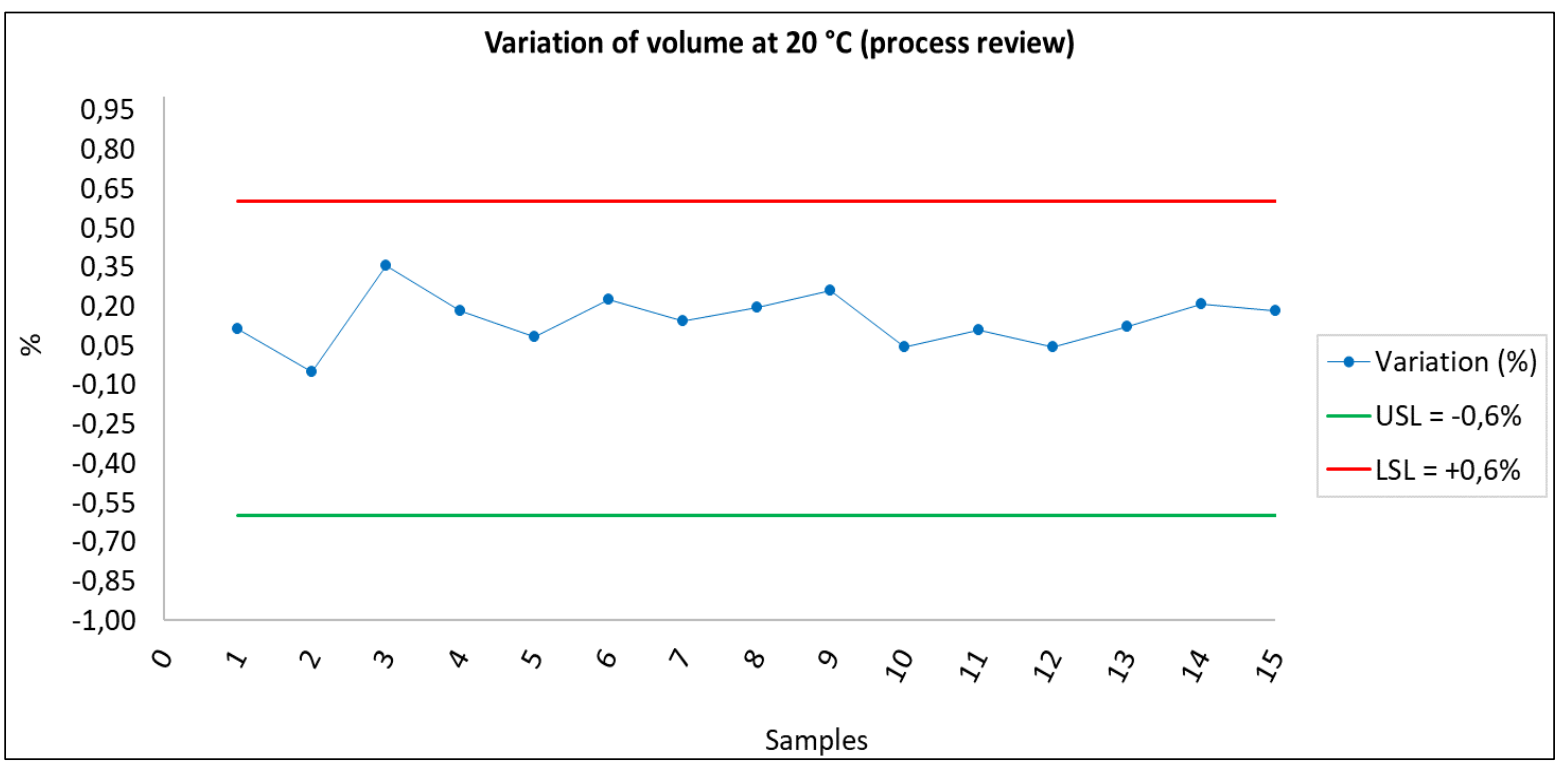

Figure 10: Graph of values and specification limits for Volume at $20{ }^{\circ} \mathrm{C}$ - process review. Source: Authors, (2020).

Figure 11 shows the control chart of the individual values for the Volume parameter at $20{ }^{\circ} \mathrm{C}$ for the 15 lots. In both figures, it is observed that the process remains within the control limits, which were calculated for the process, which are $-0,12$ and $+0,42 \%$ for LCL and UCL, respectively, with an average (ML) around + $0,15 \%$ for the control chart of individual values $(x)$.

The specification limit and control limit values for the individual values, evaluating the volume parameter at $20^{\circ} \mathrm{C}$, were organized in a spreadsheet and are presented in Table 5. 


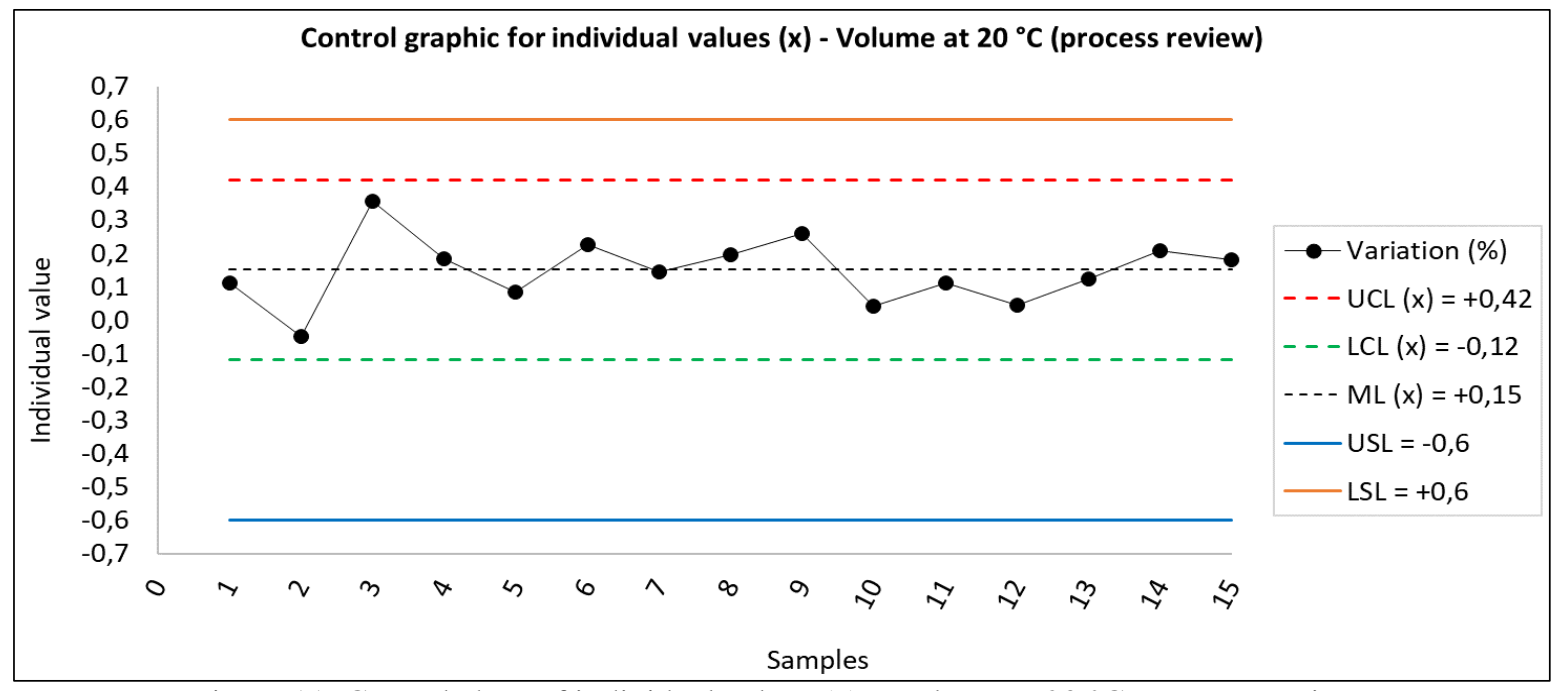

Figura 11: Control chart of individual values $(x)$ - Volume at $20^{\circ} \mathrm{C}$ - process review. Source: Authors, (2020).

\section{IV.4.3 Process Capability Assessment - Process Review}

After proving the stability of the process, the process capacity index was calculated as described in table 6 .

Table 6: Control limits and capacity study (process review).

\begin{tabular}{|c|c|c|}
\hline Parameter & Ambient volume & Volume at 20 $^{\circ} \mathbf{C}$ \\
\hline Especification limits & $-0,6 \mathrm{a}+0,6 \%$ & $-0,6 \mathrm{a}+0,6 \%$ \\
\hline Control limits (x) & $-0,34 \mathrm{a}+0,52 \%$ & $-0,2 \mathrm{a}+0,6 \%$ \\
\hline Standard deviation & 0,087 & 0,099 \\
\hline Cpi & 2,412 & 2,505 \\
\hline Cps & 2,196 & 1,515 \\
\hline Cpk = mín[Cpi,Cps] & $\mathbf{2 , 1 9 6}$ & $\mathbf{1 , 5 1 5}$ \\
\hline Conclusion & Capable process & Capable process \\
\hline
\end{tabular}

Source: Authors, (2020).

For the Ambient Volume variable, the value of $C_{p k}=2,191$, considering the standard deviation calculated for the 0,087 . Having resulted $C_{p k} \geq 1,33$ the process is qualified as Capable.

For the variable Volume at $20{ }^{\circ} \mathrm{C}$, the value of $C_{p k}=1,515$, considering the standard deviation calculated for the 0,099 . Having resulted $C_{p k} \geq 1,33$ the process is qualified as Capable.

\section{CONCLUSIONS}

In this work, Statistical Process Control (SPC) was used to demonstrate the performance of changes in the volume of gasoline A during the transfer process between tanks at a fuel distributor in the city of Manaus / AM and to establish a study for the use of this tool control.

An analysis of the graphs described in Figures 8, 9, 10 and 11 and Table 6, show that the process is capable of meeting all control specifications from a review of the process that was followed up in August and September of 2020. All the process control parameters studied, ambient volume and volume at $20^{\circ} \mathrm{C}$, remained within the control limits and as for the capacity indexes, it was concluded that the process produced high capacity indexes.

The SCP used here enabled the use of information accumulated in historical receipt data that had not been used for other purposes, allowing the knowledge of the levels of variation produced by the process, which can be a starting point for implementing a process of continuous improvement.

The use of SCP is also a systematic of continuous process validation, since it can be managed continuously. The use of SCP enabled the unveiling of unnoticed instabilities by simply comparing the targets to specifications and an opportunity to trigger continuous improvement actions.

\section{AUTHOR'S CONTRIBUTION}

Conceptualization: Everaldo de Queiroz Lima and Fátima Geisa Mendes Teixeira.

Methodology: Everaldo de Queiroz Lima and Fátima Geisa Mendes Teixeira.

Investigation: Everaldo de Queiroz Lima.

Discussion of results: Everaldo de Queiroz Lima and Cecília Lenzi.

Writing - Original Draft: Everaldo de Queiroz Lima.

Writing - Review and Editing: Everaldo de Queiroz Lima and Cecília Lenzi.

Resources: Everaldo de Queiroz Lima.

Supervision: Cecília Lenzi and Maurício Moyses Machado.

Approval of the final text: Everaldo de Queiroz Lima and Cecília Lenzi.

\section{ACKNOWLEDGMENTS}

MSc. Cecília Lenzi for guidance, to the Lutheran University Center of Manaus (CEULM-ULBRA) and Coordination of the Graduation in Chemical Engineering for the availability of the course, structure and management.

\section{REFERENCES}

[1] Costa, A. F. B.; Epprecht, E.; Carpinetti, L. C. R. "Controle Estatístico de Qualidade". Editora Atlas, $1^{\circ}$ ed., São Paulo, 2004.

[2] Royalfic. "Fatores responsáveis por perdas de combustíveis". Site Royal FIC, 2018. Available: https://www.royalfic.com.br/conheca-7-fatores-responsaveis-porperdas-de-combustivel-nos-postos/ [Accessed July 16, 2020].

[3] Diniz, A. F.; Schoendorfer, C. L.; Siqueira, L. C. G. "Estimated emission of volatile organic compounds from a fueling station and its impact on the environment". Anais, XIV Safety, Health and Environment Wolrd Congress, Cubatão, 2014.

[4] BRASILPOSTOS. "Perdas de combustíveis que geram prejuízos". Site da Brasil Postos, 2018. Available: https://www.brasilpostos.com.br/noticias/equipamentos/medidor-volumetrico-decombustiveis/8-tipos-de-perdas-de-combustiveis-que-geram-prejuizo-na-revenda/ [Accessed July 16, 2020]. 
[5] BRASIL. "Institucional - Atribuições da ANP". Agência Nacional de Petróleo, Gás Natural e Biocombustíveis, 2020. Available: http://www.anp.gov.br/institucional [Accessed July 17, 2020].

[6] Lima, A. A. N.; Lima, J. R.; Silva, J. L.; Alencar, J. R. B.; Soares, J. L.; Lima, L. G.; Rolim, P. J. "Application of statistical process control in the pharmaceutical industry”. Revista Ciências Farmacêuticas Básica Aplicada, v. 27, n.3, p. 177-187, 2006.

[7] Ramos, A. W. "CEP para processos contínuos e em bateladas". Fundação Vanzolini, ed. Edgar Blucher, $1^{\circ}$ ed., São Paulo, 2012.

[8] Henning, E., Walter, O. M. C. F., Souza, N. S., Samohyl, R. W. "A study for the application of statistical process control charts in water quality indicators". Rev. Sistema e Gestão, pag. 2-13, vol. 09, n01, 2014.

[9] Ribeiro, J. L. D. E Caten, C. S. T. "Controle Estatístico do Processo". FEENG - UFRGS, Porto Alegre, 2012.

[10] Maciel, J. C. S. L. "Study of the liquid-vapor balance of the water + ethanol + ionic system aiming at the separation of anhydrous alcohol". Dissertação, 128 p. Engenharia Química, Universidade Federal do Rio Grande do Norte, Natal, 2012.

[11] Louzada, F.; Diniz, C.; Ferreira, P.; Ferreira, E. "Controle Estatístico de Processo: Uma abordagem prática para engenharia”. Editora LTC, $1^{\circ}$ ed., Rio de Janeiro, 2013.

[12] Montgomery, D. C. "Introdução ao controle estatístico da qualidade". $4^{\circ}$ ed., John Wiley \& Sons, Inc., 2001.

[13] Fernandes, F. A. N.; Pizzo, A. M.; Júnior, D. M. "Termodinâmica Química". Editora UFC, $1^{\circ}$ ed., Fortaleza, 2006.

[14] BRASIL. "Resolução ANP n. 58/2014 - Regulamentação de atividade de distribuição de combustíveis no Brasil”. Agência Nacional de Petróleo, Gás Natural e Biocombustíveis, DOU 20/10/2014. Available: http://legislacao.anp.gov.br/?path=legislacao-anp/resol-

anp/2014/outubro\&item=ranp-58-2014 [Acessed June 15, 2020].

[15] BRASIL. "Norma Regulamentadora ${ }^{\circ} 20$ - Saúde e Segurança no Trabalho com Inflamáveis e Combustíveis. Ministério do Trabalho, DOU 06/07/1978". Available: https://enit.trabalho.gov.br/portal/images/Arquivos_SST/SST_NR/NR20-atualizada-2019.pdf [Acessed June 7, 2020].

[16] Follmer, E. "Implementation of statistical process control in one step of the wire galvanizing process: case study in the acid pickling process". Trabalho de Conclusão de Curso, 29 p., Engenharia de Produção, Pontifícia Universidade Católica do Rio Grande do Sul, Porto Alegre, 2013.

[17] PORTAL ACTION. "Controle Estatístico de Processo, 2020". Available: http://www.portalaction.com.br/controle-estatistico-do-processo [Acessed May 12, 2020].

[18] BRASIL. "NBR 13787 - Armazenamento de Combustíveis Líquidos e Inflamáveis". $\quad 2^{\circ}$ ed. Rio de Janeiro, 2013. Available: https://www.docsity.com/pt/nbr-13787-controle-de-estoque-dos-sistemas-dearmazenamento-subterraneo-de-combustiveis-s/4782172/ [Acessed October 15, 2020].

[19] BRASIL. "Resolução ANP n. 23/2004 - Regulamentação de Estoques de Combustíveis". Agência Nacional de Petróleo, Gás Natural e Biocombustíveis, DOU 20/10/2014. Available: http://legislacao.anp.gov.br/?path=legislacaoanp/resol-anp/2004/novembro\&item=ranp-23--2004 [Acessed October 15, 2020]. 